\title{
YIELD STABILITY EVALUATION FOR BREAD WHEAT GENOTYPES UNDER ENVIRONMENTAL VARIATIONS
}
M. A. H. Al-Falahi*
Kh. M. Dawod**
Fathi. A. Omer*
Prof.
Prof.
Assistant Prof.
* College of Agricultural Engineering Sciences, University of Duhok
** College of Agriculture and Forestry, University of Mosul
E-mail: fathiemenky@uod.ac

\section{ADSTRACT}

This study was aimed to evaluation the yield stability of twenty bread wheat genotypes that cultivated at two locations (fields of the College of Agricultural Engineering Sciences of Duhok and Zenawa district) during the 2019 - 2020 with two planting dates in each location using randomized complete block design with three replications. The results of the combined analysis of variance showed that the mean square for each of the environments, genotypes and their interactions were highly significant for all studied traits, and the variations due to the environments were greater than those of each of the genotypes and the interactions for most of the studied traits. The values of broad sense heritability ranged between $44.44 \%$ for spike length and $93.27 \%$ for grain weight per spike. The results of the stability parameters showed that the genotype Apst-12-85578 was highly stable for grains weight per spike and final grain yield followed by each of Adana, Bora, and Apst-6-85576 genotypes which showed high stability for the grain yield.

KeyWords: gain yield, combined analysis, heritability, environments,

الفلاحي وآخرون

مجلة العلوم الزراعية العراقية - $1460-1449: 52:$ (6) مجل

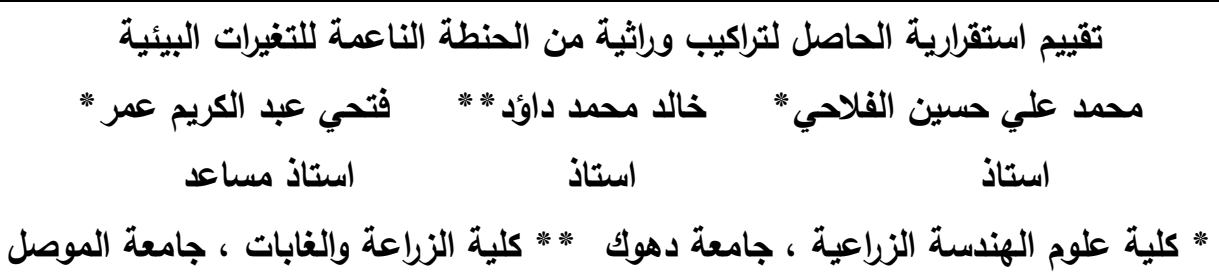

المستخلص

تهذف الدراسة الى تقيم الحاصل لـ 20 تركيب وراثي من حنطة الخبز في موقعين (حقول كلية علوم الهندة الزراعية الزراعة بجامعة دهوك ومنطقة زيناوه) خلال الموسم الزراعي 2019 و2020 وموعدين للزراعة باستعمال تصميم القطاعات العشوائية الكاملة بثلاثة مكررات. اظهرت نتائج تحليل التباين التجميعي ان متوسط مربعات كل من البيئات والتراكيب الوراثية وتداخل التراكيب الوراثية x البيئات كان معنوياً بشكل عالي للصفات جميعها، وكانت الاختلافات العائدة إلى البيئات اكبر كثيراً من تلك مئك العائدة لكل من التراكيب الوراثية والتداخل لمطم الصفات وتباينت نسبة التوريث بالمعنى الواسع بين 44.44\% لطول السنبلة و93.27\% لوزن الحبوب بالسنبلة. بينت نتائج معدلات الاستقرارية ان التركيب الوراثي Apst-12-85578 كانت استقراريته عالية لوزن الحبوب بالسنبلة وحاصل الحبوب ثم التراكيب الوراثية الثلاث Adana و Bora و التي اظهرت استقرارية عالية لحاصل الحبوب. الكلمات المفتاحية: استقرارية الحاصل، التحليل الارتباطي، التوريث، البيئات 


\section{INTRODUCTION}

Wheat (Triticum aestivum L.) is the most important cereal crop for many countries of the world, including Iraq, and it is also a major component of the diet of these countries through which food security is achieved $(1,19$ and 20) which source of food for more than $35 \%$ of the world's population (22). Environmental factors, including non-vital (e.g. soil, fertility status, temperature, seeding time, day of length, etc.) and vital (e.g. pests and diseases) are unstable from one agricultural season to another, as well as across different locations, and thus affect the stability performance of bread wheat genotypes (4). Wheat grain yield and its components with other traits depend in terms of their performance on the nature of the genotype, environmental conditions and the interaction of the genotype with the environment (15). Stability of grain yield specifications and other traits of the genotypes across a wide range of environmental changes is a source of great interest by plant breeders and agronomists. Also, Liu (18) stated that forecasts indicate an increase in the negative frequency of the extremely low yield due to adverse weather conditions. Kahiluoto (16) indicated that homogeneous European wheat varieties lack flexibility in dealing with climate instability, therefore, it is necessary to build sustainable systems through which varieties that are genetically stable can be adopted for their performance under different environmental conditions, thus ensuring food security through stabilizing agricultural production. An increase of diversity within was reported by (14) through cultivating ancient races or varieties by mixing or hybridizing varieties, and by developing populations of synthetic hybrids or open pollination varieties. Where Reiss and Drinkwater (21) confirmed that the indeterminate diversity gives the cultivated crops the ability to adapt to environmental changes and stabilize production. Accordingly, studies of genotype with environment interaction provide the basis for the selection of genotypes that are suitable for general agriculture in a wide range of environmental changes and others for specific regions under specific environments (17). Also, Yang, and
Baker (25) illustrated that the resultant of instability among genotypes from one environment to another may arise as a result of the method of expression of different groups of genes in different environments or the difference in the responses of the same group of genes to different environments. The consistency of the grain yield between genotypes can be expressed as a linear response to the environmental benefit and a deviation from that response (21). The ideal genotype generally exhibits low variation of environmental genetic interaction, above the response rate to the environmental gain, and less deviations from the expected response within the target environment. The stability of the yield and its components from other traits can be described through the pooled variance analysis using a regression coefficient according to the method proposed by (11) for barley genotypes; they suggest that the genotype that has a high rate of the trait and a regression coefficient close to one is of an appropriate average stability and is described as being widely adaptive and that its performance is fixed and stable across all environments. Accordingly, a genotype with a regression coefficient of less than one is considered specifically adaptive to severe environmental conditions (unsuitable). While that with a regression coefficient greater than one genotype is considered has a specific adaptation to the appropriate environments (with high production or performance). Likewise, Eberhart, and Russell (9) used the regression coefficient as a parameter of stability and measured the regression of average yield for each genotype over the average yield of all genotypes for each environment (the environmental index); their method suggests that the genotype is stable or adaptive to a wide range of environmental changes if it has a high average yield, a regression coefficient close to one, and the lowest value of the deviation from the regression (close to zero). Although many other methods are used to analyze the stability of the genotypes of different environments (22), the above-mentioned methods are still more popular for this purpose. Therefore, stability studies (environmental genetic interaction) are of great importance to identify 
the distinct genotypes that have good performance across a wide range of environmental changes and to reveal the extent to which specific genotypes adapt to suitable or inappropriate environments. The aim of the current study is to evaluate the performance of a group of introduced bread wheat genotypes across different environments.

\section{MATERIALS AND METHODS}

Twenty genotypes of bread wheat (Triticum aestivum L.) were adopted in the current study (Table 1). The seeds of these genotypes were planted under rainy conditions at two locations, the first at the fields of the College of Agricultural Engineering Sciences, Duhok, and the second at the Zenawa region (located $85 \mathrm{~km}$ east of Duhok), and in two dates of sowing in each location, the first date on November, 25 and the second date on December, 25 .Data in Table 2 shows the amounts of rainfall $(\mathrm{mm})$ and its distribution through the growing season in the both locations. The field soil was prepared by plowing by mold board plow twice and in a perpendicular manner, then smoothing, leveling and planning operations were carried out for each location.

Table 1. Genotypes used in the study and their sources

\begin{tabular}{|lll|lll|}
\hline$\#$ & Genotype & Source & $\#$ & Genotype & Source \\
\hline $\mathbf{1}$ & Italy & Italia / not certified & 11 & Azady & Kurdistan region / certified \\
2 & Adana & Kurdistan region / certified/ & $\mathbf{1 2}$ & IPA 99 & Baghdad / certified \\
3 & Criso & Kurdistan region / certified & $\mathbf{1 3}$ & IPA 95 & Baghdad / certified \\
4 & Tamoz2 & Baghdad / certified & 14 & Buhoth 4 & Sulaymaniyah / certified \\
$\mathbf{5}$ & Bora & Kurdistan region / certified & $\mathbf{1 5}$ & Apst-35-85574 & Italy / not certified \\
$\mathbf{6}$ & Jehan 99 & Kurdistan region / certified & $\mathbf{1 6}$ & Apst-33-85577 & Italy / not certified \\
7 & Hawlier & Kurdistan region / certified & $\mathbf{1 7}$ & Apst-6-85576 & Italy / not certified \\
$\mathbf{8}$ & Adana 99 & Kurdistan region / certified & $\mathbf{1 8}$ & Apst-36-85575 & Italy / not certified \\
$\mathbf{9}$ & TAWA-HI-3 & ICARDA & 19 & Apst-12-85578 & Italy / not certified \\
10 & BABAGA-3 & ICARDA & $\mathbf{2 0}$ & Apst-26-85579 & Italy / not certified \\
\hline
\end{tabular}

Table 2. Amounts of rainfall $(\mathrm{mm})$ during the growing season in the study locations

\begin{tabular}{|lccccccccc|}
\hline \multirow{2}{*}{ Months } & October & November & December & January & February & March & April & May & Total \\
& 2019 & 2019 & 2019 & 2020 & 2020 & 2020 & 2020 & 2020 & \\
\hline Duhok & 43.34 & 19.3 & 137.8 & 110.7 & 101.7 & 282.0 & $\mathbf{6 8 . 5}$ & $\mathbf{1 6 . 2}$ & $\mathbf{7 7 9 . 5 4}$ \\
Zenawa & $\mathbf{8 . 0}$ & $\mathbf{5 . 0}$ & 155.0 & $\mathbf{1 4 8 . 0}$ & $\mathbf{1 1 6 . 0}$ & $\mathbf{2 1 6 . 0}$ & $\mathbf{4 3 . 0}$ & $\mathbf{9 . 0}$ & $\mathbf{7 0 0 . 0}$ \\
\hline
\end{tabular}

The planting was in lines $0.30 \mathrm{~m}$ apart. Compound fertilizer (NPK 20:20:20) was added at a rate of $120 \mathrm{~kg}$ per hectare during land preparation before planting, and urea fertilizer $(\mathrm{N} \%$ 46) at a rate of $160 \mathrm{~kg}$ per hectare in two periods, the first in the tillering stage and the second before flowering. In each location, an experiment was carried out that included 40 treatments of combination (which is a combination of the twenty genotypes and planting dates) using a randomized complete block design with three replications. Each experimental unit contained three lines of $3 \mathrm{~m}$ length. Weed control was carried out with the Topic pesticide for narrow leaved and Granstar for broad-leaved at 2-3 leaf stage for both types of weeds, with the scientifically recommended dosages for each pesticide. Data were recorded on plant height $(\mathrm{cm})$, spike length $(\mathrm{cm})$, number of seeds per spike, seed weight in spike $(\mathrm{g}), 1000$ seed weight $(\mathrm{g})$, leaf area $\left(\mathrm{cm}^{2}\right)$, grain yield per unit area $(\mathrm{g} / 0.9 \mathrm{~m})$ and grain yield ( $\mathrm{kg}$ Per hectare). A combined analysis of variance for genotypes traits data across location was performed according to the method of experimental design used, as well as an analysis of variance of genotypes across environments (twenty genotypes and four agricultural environments, where the combinations between planting dates and the two locations were considered different environments) was calculated. Differences among the means of the genotypes and the four environments were compared by Duncan's Multiple Range Test method (3). The phenotypic variance components and broad sense heritability $\left(\mathrm{H}_{\mathrm{BS}}\right)$ were estimated in the manner indicated by Demir and Turgut (8) from the equation:

$\mathrm{H}_{\mathrm{BS}}=\varnothing \mathrm{g} / \varnothing \mathrm{ph}=\emptyset \mathrm{g} /(\varnothing \mathrm{g}+\emptyset \mathrm{gl} / 1+\emptyset \mathrm{gd} / \mathrm{d}$ $+\varnothing \mathrm{gld} / \mathrm{ld}+\varnothing \mathrm{e} / \mathrm{ldr}$ ) Where $\emptyset \mathrm{g}$ total genetic variance, $\varnothing \mathrm{ph}$ phenotypic variation, $\emptyset \mathrm{gl}$ variance of genotypes with locations interaction, $\varnothing \mathrm{gd}$ variance of genotypes with planting dates interaction, Øgld variance of genotypes with both locations and planting 
dates interaction, Øe environmental variance, (l) number of locations, (d) planting dates and (r) number of replicates, as well as the expected genetic advance in the next generation as a percentage of the trait mean was estimated. To test the genetic stability of the twenty genotypes at different environments adopted in the study, the linear regression model proposed by Eberhart, and Russel (9) was used, namely:

$\mathrm{y}_{\mathrm{ij}}=\mu+\mathrm{b}_{\mathrm{i}} \mathrm{I}_{\mathrm{j}}+\mathrm{z}_{\mathrm{ij}}+\mathrm{e}_{\mathrm{ij}}$,

where $y_{i j}$ refer to the mean genotype (i) in the environment (j) and $b_{i}$ is the regression coefficient of the genotype (i) at the specific environmental index, which means the response of the genotype to environmental change, $\mathrm{I}_{\mathrm{i}}$ is the environmental index, which is defined as the deviation of the mean of all genotypes in a specific environment from the general mean, $\delta_{i j}$ the deviation from the regression for genotype (i) at environment $(\mathrm{j})$ and $\mathrm{e}_{\mathrm{ij}}$ the mean experimental error. Two parameters of stability were estimated according to the steps explained by AlZubaidy and Al-Falahy, (2), first regression coefficient $\left(b_{i}\right)$ using the equation: $b_{i}=\sum y_{i j} I_{i} /$ $\sum \mathrm{I}_{\mathrm{i}}{ }^{2}$, noting that $\mathrm{y}_{\mathrm{ij}} \mathrm{I}_{\mathrm{i}}$ is the sum of product, $\sum \mathrm{I}_{\mathrm{i}}{ }^{2}$, the sum of squares, and second the mean deviation from the linear regression $\left(\mathrm{S}^{2} \mathrm{~d}_{\mathrm{i}}\right)$ which is equal to: $\left[\sum \delta_{\mathrm{ij}}{ }^{2} /(\mathrm{s}-2)\right]-\mathrm{Se}^{2} / \mathrm{r}$, where $\sum^{\delta} \mathrm{ij}^{2}=\left[\sum \mathrm{y}_{\mathrm{ij}}{ }^{2}-\mathrm{Y}_{\mathrm{i}}{ }^{2} / \mathrm{t}\right]-\left(\sum \mathrm{y}_{\mathrm{ij}} \mathrm{I}_{\mathrm{i}}\right)^{2} / \sum \mathrm{I}_{\mathrm{i}}{ }^{2}$ and $\mathrm{Se}^{2}$ is an estimate of the combined error. The significance of the regression coefficient from zero for each trait was tested by calculating the standard error value of the regression coefficient, as the linear regression coefficient of the relationship between each trait of the genotype in each environment and the yield and performance of each trait of the environment rate is a measure of the linear response to environmental changes, and the average variance of the deviation from the regression $\left(S^{2} d_{i}\right)$ measures the consistency of this response, or in other words, it is a measure of heterogeneity. Likewise, the genotypes (for the grain yield trait as the most important trait and the final result of its components from other traits) were distributed according to the values of their regression coefficients and means in the stability triangle in the manner explained by Ellis (10), and in which: first, the genotypes near the end of the head of the triangle are very adaptive for all environments, second, those located at the top corner of the base are adapted to the preferred environments, third, those located to the far left of the stability line of the rate are weakly adapted to all environments, while forth, those located below the triangle and to the left are considered adapted to the non-preferred environments. The Microsoft office excel, Statistical Analysis System (SAS) and Minitab were used to implement the statistical procedures.

\section{RESULTS AND DISCUSSION}

Table 3 shows the results of combined analysis of variance of the data for the traits of bread wheat genotypes planted in two different dates and locations, and it is noticed that the mean square of each of the locations, planting dates and genotypes was significant at a $1 \%$ probability level for all the traits under study except for the leaf area in the case of locations (where it doesn't reach the significant limits). Also, the mean square of the interactions of genotypes with each of planting dates, locations and both appeared highly significant for all traits. The significance of all interactions of genotypes for all traits indicates the difference in the behavior of some of them according to the different environmental conditions in which they grow.

Table 3. Combined variance analysis of genotypes planted at two dates across two locations.

\begin{tabular}{|c|c|c|c|c|c|c|c|c|}
\hline \multirow[b]{2}{*}{ SOV } & \multirow[b]{2}{*}{ df } & \multicolumn{7}{|c|}{ Traits } \\
\hline & & $\begin{array}{l}\text { Plant height } \\
\text { (cm) }\end{array}$ & $\begin{array}{l}\text { Spike } \\
\text { length } \\
(\mathbf{c m})\end{array}$ & $\begin{array}{l}\text { No. seeds } \\
\text { per spike }\end{array}$ & $\begin{array}{c}\text { Seeds } \\
\text { weight per } \\
\text { spike }\end{array}$ & $\begin{array}{c}1000 \text { seeds } \\
\text { weight (gm) }\end{array}$ & $\begin{array}{l}\text { Leaf area } \\
\qquad\left(\mathrm{cm}^{2}\right)\end{array}$ & $\begin{array}{c}\text { Grain } \\
\text { yield } \\
\text { (ton/ha) }\end{array}$ \\
\hline locations & 1 & $9188.44 * *$ & $22.44 * *$ & $1288.1 * *$ & $\mathbf{0 . 3 0 3} * *$ & $342.15 * *$ & 0.20 & 28.32** \\
\hline Reps./ loc. & 4 & 1.321 & 0.47 & 1.89 & 0.022 & 1.12 & 3.51 & 0.156 \\
\hline Dates & 1 & $1776.7 * *$ & $66.71 * *$ & $160.07 * *$ & $0.572 * *$ & $23.90 * *$ & $937.53 * *$ & $5.66 * *$ \\
\hline Genotypes & 19 & $991.79 * *$ & $11.24 * *$ & $119.89 * *$ & $1.373 * *$ & $438.56 * *$ & $360.97 * *$ & $4.43 * *$ \\
\hline Gen $x$ Date & 19 & $164.83 * *$ & $3.73 * *$ & $6.26 * *$ & $0.037 * *$ & $35.74 * *$ & $108.01 * *$ & $0.149 * *$ \\
\hline Date $x$ Loc. & 1 & 3.038 & $53.89 * *$ & $205.35 * *$ & $0.115 * *$ & $28.32 * *$ & $436.40 * *$ & 0.064 \\
\hline Gen.x Loc. & 19 & $557.26 * *$ & $6.91 * *$ & $21.49 * *$ & $0.043 * *$ & $39.75 * *$ & $237.49 * *$ & $1.21 * *$ \\
\hline G.x D.x L. & 19 & $110.23 * *$ & $3.489 * *$ & $5.39 * *$ & $0.024 * *$ & $17.39 * *$ & $146.66 * *$ & $0.16 * *$ \\
\hline Error & 156 & 4.603 & 0.104 & 0.789 & 0.0021 & 0.173 & 0.899 & 0.023 \\
\hline
\end{tabular}

Where: (**) Significant at $1 \%$ probability, G; Genotypes, D; Dates, loc.; Locations 
Results in Table 4-a show the combined analysis of variance of the data of the traits of bread wheat genotypes across different environments (four environments resulting from the combinations of locations with planting dates), and it is revealed that the mean square of each of the environments, genotypes and the interaction between them was highly significant for all traits. The significant genotypes $\mathrm{x}$ environment interaction for all traits indicate the difference in the behavior of some genotypes according to the different environmental conditions in which they grow. genotypes and the interaction between them differed from each other in their relative importance towards the traits under study. It is clear that the differences due to the environments were much greater than those related to both the genotypes and the interaction for most of the traits, except for seed weight per spike and 1000 grains weight, as the differences related to the genotypes were greater, while the differences caused by the genotypes $x$ environments interaction were less than that in each of the genotypes and environments for all traits.

It is also showed that the environments,

Table 4. Analysis of variance results of genotypes in different environments help in studying their stability for the studied traits

\begin{tabular}{|c|c|c|c|c|c|c|c|c|}
\hline \multirow[b]{2}{*}{ SOV } & \multirow[b]{2}{*}{ df } & \multicolumn{7}{|c|}{ Traits } \\
\hline & & $\begin{array}{l}\text { Plant } \\
\text { height } \\
(\mathbf{c m})\end{array}$ & $\begin{array}{c}\text { Spike } \\
\text { length } \\
(\mathbf{c m})\end{array}$ & $\begin{array}{l}\text { No. seeds } \\
\text { per spike }\end{array}$ & $\begin{array}{c}\text { Seeds } \\
\text { weight per } \\
\text { spike }\end{array}$ & $\begin{array}{c}1000 \text { seeds } \\
\text { weight } \\
\text { (gm) }\end{array}$ & $\begin{array}{c}\text { Leaf area } \\
\left(\mathrm{cm}^{2}\right)\end{array}$ & $\begin{array}{c}\text { Grain } \\
\text { yield } \\
\text { (ton/ha) }\end{array}$ \\
\hline \multicolumn{9}{|c|}{ a : Combining analysis according to the method of randomized complete block design } \\
\hline Env. & 3 & $3656.1 * *$ & $47.69 * *$ & $551.16 * *$ & $0.331 * *$ & $131.46 * *$ & $458.05 * *$ & $11.35^{* *}$ \\
\hline Reps./Env. & 8 & 5.708 & 0.302 & 1.050 & 0.014 & 0.641 & 4.96 & 0.113 \\
\hline Genotypes & 19 & $991.79 * *$ & $11.24 * *$ & $119.88 * *$ & $1.373 * *$ & 438.56** & $360.97 * *$ & $4.43 * *$ \\
\hline Gen. $x$ Env. & 57 & $277.44 * *$ & $4.71 * *$ & $11.04 * *$ & $0.035 * *$ & $30.96 * *$ & $164.05 * *$ & $0.505^{* *}$ \\
\hline Error & 152 & 4.458 & 0.103 & 0.804 & 0.0020 & 0.173 & 0.754 & 0.022 \\
\hline \multicolumn{9}{|c|}{ b : Analysis as a factorial experiment according to the method completely randomized design } \\
\hline Env. & 3 & 3656.059 & 0.801 & 551.161 & 0.3298 & 131.458 & 458.045 & 11.347 \\
\hline Genotypes & 19 & 991.785 & 47.684 & $\mathbf{1 1 9 . 8 8 7}$ & 1.3724 & 438.562 & 360.966 & 4.427 \\
\hline Gen. $x$ Env. & 57 & 277.439 & 11.239 & 11.038 & 0.0344 & 30.959 & 164.052 & 0.505 \\
\hline Error & 160 & 4.552 & 0.113 & 0.817 & 0.0026 & 0.196 & 0.0 .964 & 0.026 \\
\hline \multicolumn{9}{|c|}{ c : Analysis as a factorial experiment of traits means across replicates } \\
\hline Env. & 3 & 330.595 & 3.746 & 39.962 & 0.4575 & 146.187 & 120.322 & 1.476 \\
\hline Genotypes & 19 & 1218.687 & 15.895 & 183.720 & 0.1099 & 43.819 & 152.682 & 3.782 \\
\hline Gen. $x$ Env. & 57 & 92.479 & 1.570 & 3.679 & 0.0115 & 10.319 & 54.684 & 0.168 \\
\hline
\end{tabular}

Where: (**) Significant at 1\% probability, Env.; Environments

The results shown in Table 4- represent the results of the statistical analysis of data according to the analysis of complete randomized design and the means of genotypes across replicates respectively to be used in completing the requirements of the analysis of variance for the stability of genotypes across different environments. In Table 5 the components of variance and some genetic parameters are evident, and from the results, it is observed that the values of the determination coefficient were high for all traits (between $97.38 \%$ and $99.74 \%$ ) indicating that more than $97 \%$ of the variations in all traits are explained by differences in genotypes and environmental conditions, as well as It is also noted that the highest value of the coefficient of variability was $4.171 \%$ for grain yield, followed by spike length and grain weight per spike $(3.449 \%$ and $3.303 \%$ respectively). This means that the random environmental fluctuations caused greater changes in these three traits, although Budak (5) reported that the values of the coefficient of variability are not constant in the different studies, and the reason for this is due to the difference in genotypes or environmental conditions. In contrast it is indicated that broad sense heritability was high for traits: number of grains per spike, grains weight per spike, 1000 grains weight and grain yield, and moderate for plant height, spike length and leaf area $(54.53 \%, 44.44 \%$ and $42.43 \%$ respectively), and this means that these three 
traits are more sensitive to inappropriate environmental conditions as compared with other traits, indicating that there is tension during the reproduction and maturity stages causing a decrease in their inheritance, as well as indicating that these traits are genetically controlled and that the environmental effects on them is greater.

Table 5. Variance components, heritability, and expected genetic advance of studied traits.

\begin{tabular}{|c|c|c|c|c|c|c|c|}
\hline \multirow[b]{2}{*}{$\begin{array}{c}\text { Genetic } \\
\text { parameters }\end{array}$} & \multicolumn{7}{|c|}{ Traits } \\
\hline & $\begin{array}{c}\text { Plant } \\
\text { height } \\
\text { (cm) }\end{array}$ & $\begin{array}{c}\text { Spike } \\
\text { length } \\
\text { (cm) }\end{array}$ & $\begin{array}{l}\text { No. seeds } \\
\text { per spike }\end{array}$ & $\begin{array}{c}\text { Seeds } \\
\text { weight per } \\
\text { spike }\end{array}$ & $\begin{array}{c}1000 \text { seeds } \\
\text { weight } \\
(\mathrm{gm})\end{array}$ & $\begin{array}{l}\text { Leaf area } \\
\quad\left(\mathrm{cm}^{2}\right)\end{array}$ & $\begin{array}{c}\text { Grain yield } \\
\text { (ton/ha) }\end{array}$ \\
\hline$\phi^{2} g$ & 82.265 & 0.928 & 9.925 & 0.114 & 36.532 & 30.006 & 0.367 \\
\hline$\phi^{2} \mathrm{gl}$ & 92.109 & 1.134 & 3.449 & 0.007 & 6.595 & 39.431 & 0.197 \\
\hline$\phi^{2} \mathrm{gd}$ & 26.704 & 0.605 & 0.912 & 0.006 & 5.928 & 17.852 & 0.021 \\
\hline$\phi^{2}$ gdl & 35.209 & 1.128 & 1.526 & 0.007 & 5.739 & 48.587 & 0.046 \\
\hline$\phi^{2} \mathrm{e}$ & 4.603 & 0.104 & 0.789 & 0.0021 & 0.173 & 0.899 & 0.023 \\
\hline$\phi^{2} \mathrm{ph}$ & 150.858 & 2.088 & 12.553 & 0.122 & 44.243 & 70.869 & 0.489 \\
\hline heritability & 0.5453 & 0.4444 & 0.7906 & 0.9327 & 0.8257 & 0.4234 & 0.7499 \\
\hline $\mathbf{R}^{2}$ & 0.9845 & 0.9748 & 0.9738 & 0.9888 & 0.9974 & 0.9921 & 0.9763 \\
\hline $\mathrm{CV}$ & 2.870 & 3.449 & 2.534 & 3.303 & 1.078 & 2.703 & 4.171 \\
\hline GA & 11.788 & 1.130 & 4.930 & 0.574 & 9.666 & 6.273 & 0.923 \\
\hline GA\% $\%$ & 15.771 & 12.102 & 14.063 & 41.353 & 25.065 & 17.882 & 25.407 \\
\hline Mean & 74.746 & 9.339 & 35.058 & 1.389 & 38.566 & 35.081 & 3.634 \\
\hline
\end{tabular}

Finally, the expected genetic advance values as percent of the mean of each trait in the next generation was high for grain weight per spike and moderate for other traits. The lowest value was $12.102 \%$ for spike length, $14.063 \%$ for number of grains per spike, and $15.771 \%$ for plant height. The reflection of the analysis of variance results is noted on the comparison between the means of genotypes as an average for different environments (Table 6) and the means of environments as average of genotypes (Table 7). It is evident that the genotype Apst-26-85579 produced the highest grain yield per hectare (4.793 tons), with an increase over the general mean by a percentage $31.893 \%$, and over the two genotype that follows it in importance (Jehan 99 and Apst-35-85574) by percentage of $1.525 \%$ and $2.022 \%$ respectively. The superiority of this genotype was significant over all other genotypes except Jehan 99 and Apst-35-85574, while the Azadi genotype gave the lowest grain yield per hectare, which is 2.579 tons, less than the surpassed genotype by $85.847 \%$. Among the environments, it is noticed that the highest grain yield per hectare was 4,147 tons at the field of Agriculture College location and the early date of cultivation, with a significant difference from the means of the other three environments, and with an increase of $14.117 \%$ over the general mean and by $8.902 \%$ over the next environment in production, which is the same location and the late date of cultivation. It is revealed that the two planting dates at the College of Agriculture location gave a higher yield of grains per hectare than those at the Zenawa location, the reason for this may be due to the quantities and quality of rain distribution through the months of the agricultural season at the College of Agriculture location as compared to the Zenawa location. 
Table 6. Means of genotypes for studied traits.

\begin{tabular}{|c|c|c|c|c|c|c|c|}
\hline \multirow[b]{2}{*}{$\begin{array}{c}\text { Genetic } \\
\text { parameters }\end{array}$} & \multicolumn{7}{|c|}{ Traits } \\
\hline & $\begin{array}{c}\text { Plant height } \\
(\mathbf{c m})\end{array}$ & $\begin{array}{c}\text { Spike length } \\
(\mathrm{cm})\end{array}$ & $\begin{array}{c}\text { No. seeds per } \\
\text { spike }\end{array}$ & $\begin{array}{c}\text { Seeds weight } \\
\text { per spike }\end{array}$ & $\begin{array}{c}1000 \text { seeds } \\
\text { weight }(\mathrm{gm})\end{array}$ & $\begin{array}{c}\text { Leaf area } \\
\left(\mathrm{cm}^{2}\right)\end{array}$ & $\begin{array}{c}\text { Grain yield } \\
\text { (ton/ha) }\end{array}$ \\
\hline Italy & $69.833 \mathrm{hi}$ & $7.188 \mathrm{I}$ & 33.250 hi & $1.156 \mathrm{i}$ & $34.793 \mathbf{j}$ & 27.084 I & 3.509efg \\
\hline Adana & $78.167 \mathrm{~d}$ & $9.358 \mathrm{gh}$ & $31.833 \mathrm{k}$ & $0.993 \mathrm{k}$ & $30.333 n$ & $24.939 \mathrm{~m}$ & 3.504efg \\
\hline Criso & $71.750 \mathrm{fg}$ & $7.592 \mathrm{k}$ & 32.833 ij & $1.321 \mathrm{gh}$ & $38.784 \mathrm{f}$ & 40.599 b & $3.231 \mathrm{~h}$ \\
\hline Tamoz-2 & $73.250 \mathrm{f}$ & $9.330 \mathrm{gh}$ & $35.417 \mathrm{~d}$ & 1.457 de & $39.678 \mathrm{e}$ & $29.783 \mathrm{k}$ & $3.227 \mathrm{~h}$ \\
\hline Bora & 71.083gh & $9.485 \mathrm{fg}$ & $40.750 \mathrm{ab}$ & $1.973 \mathrm{bc}$ & $48.251 \mathrm{~b}$ & $36.965 \mathrm{e}$ & $4.617 \mathrm{~b}$ \\
\hline Jehan 99 & 83.667 b & $10.025 \mathrm{~d}$ & $40.750 \mathrm{ab}$ & $1.963 \mathrm{c}$ & $47.025 \mathrm{c}$ & $38.080 \mathrm{~d}$ & $4.721 \mathrm{ab}$ \\
\hline Hawler & $72.167 f g$ & $9.198 \mathrm{~h}$ & $33.92 \mathrm{fgh}$ & $1.149 \mathrm{i}$ & $31.965 \mathrm{~m}$ & 39.658 c & 3.557 ef \\
\hline Adana 99 & 84.000 b & $10.080 \mathrm{~cd}$ & 34.417 ef & $1.348 \mathrm{fg}$ & 38.699 f & 30.854 j & $3.774 \mathrm{c}$ \\
\hline TAWA-HI-3 & 89.667 a & 9.635 ef & 33.33 ghi & $1.472 \mathrm{~d}$ & $41.458 \mathrm{~d}$ & 37.001 e & 3.468efg \\
\hline BABAGA-3 & 89.667 a & $9.117 \mathrm{~h}$ & $34.167 \mathrm{f}$ & $1.365 \mathrm{f}$ & $38.563 \mathrm{f}$ & 27.7661 & $3.408 \mathrm{~g}$ \\
\hline Azadi & $75.000 \mathrm{e}$ & 9.820 de & 34.667 def & $1.297 \mathrm{~h}$ & $36.656 \mathrm{~h}$ & 30.614 j & $2.579 \mathrm{j}$ \\
\hline IPA 99 & 83.333 b & 10.938 a & $34.083 \mathrm{fg}$ & $1.155 \mathrm{i}$ & $34.924 \mathbf{j}$ & 34.717gh & $3.011 \mathrm{i}$ \\
\hline IPA 95 & 82.250 b & $10.339 \mathrm{c}$ & $32.250 \mathrm{jk}$ & $1.143 \mathrm{i}$ & $35.933 \mathrm{i}$ & $34.413 \mathrm{~h}$ & $3.404 \mathrm{~g}$ \\
\hline Buhoth-4 & 80.417 c & $8.609 \mathrm{i}$ & $36.250 \mathrm{c}$ & $1.422 \mathrm{e}$ & $38.202 \mathrm{~g}$ & 35.357fg & $3.588 \mathrm{de}$ \\
\hline Apst-35-85574 & $67.000 \mathrm{j}$ & 10.098cd & $40.333 \mathrm{~b}$ & $2.002 \mathrm{~b}$ & 50.333 a & $38.159 \mathrm{~d}$ & $4.698 \mathrm{ab}$ \\
\hline Apst-33-85577 & 56.833 l & $8.644 i$ & $32.417 \mathrm{jk}$ & $1.123 \mathrm{ij}$ & 32.918 I & $40.173 b c$ & $3.198 \mathrm{~h}$ \\
\hline Apst-6-85576 & $59.167 \mathrm{k}$ & $8.623 \mathrm{i}$ & $32.250 \mathrm{jk}$ & $1.158 \mathrm{i}$ & 36.101 i & $35.631 \mathrm{f}$ & $3.434 \mathrm{fg}$ \\
\hline Apst-36-85575 & $66.667 \mathrm{j}$ & $8.300 \mathrm{j}$ & 35.000 de & $1.153 \mathrm{i}$ & 32.6241 & $32.490 \mathrm{i}$ & $3.269 \mathrm{~h}$ \\
\hline Apst-12-85578 & $68.833 \mathrm{i}$ & 9.731 ef & $32.000 \mathrm{k}$ & $1.088 \mathrm{j}$ & $33.854 \mathrm{k}$ & $39.981 b c$ & $3.692 \mathrm{~cd}$ \\
\hline Apst-26-85579 & $72.167 \mathrm{fg}$ & $10.677 \mathrm{~b}$ & $41.250 \mathrm{a}$ & $2.055 \mathrm{a}$ & 50.222 a & $47.353 \mathrm{a}$ & $4.793 \mathrm{a}$ \\
\hline Mean & 74.746 & 9.339 & 35.058 & 1.389 & 38.566 & 35.081 & 3.634 \\
\hline
\end{tabular}

-The mean values followed by the same letter for each trait are not significantly different from each other

The Apst-26-85579 genotype was by highest grain yield) by the highest plant distinguished (in addition to their superiority height and grain weight per spike, and the in grain yield) by giving the highest means for same location in late planting was superior for the number and weight of grains per spike, number of grains per spike (with an 1000 grains weight and leaf area (41.25 grains, insignificant difference from early sowing) $2.055 \mathrm{gm}, 50.222 \mathrm{gm}$, and $47.353 \mathrm{~cm}^{2}$, and the largest leaf area. While the Zenawa respectively), and the highest mean for plant location, at early planting date, significantly height reached $89.667 \mathrm{~cm}$ in both TAWA-HI-3 recorded the highest mean for spike length and BABAGA-3 genotypes. In contrast, the $(10.035 \mathrm{~cm})$, compared to the other three genotypes Apst-36-85575 was inferior for environments, in the both planting dates with plant height, Italy for spike length and Adana the highest mean for 1000 grains weight. It is for number and weight of seeds per spike, concluded from the foregoing that the unequal 1000 grains weight and leaf area traits. yield rates and their components of other traits Regarding the environments, the College of are due to the genetic differences among the Agriculture location in early cultivation was genotypes and the environmental fluctuations. distinguished (in addition to their superiority

Table 7. Means of studied traits across different environments

\begin{tabular}{|c|c|c|c|c|c|c|c|c|}
\hline \multirow[b]{2}{*}{ locations } & \multirow[b]{2}{*}{ Date } & \multicolumn{7}{|c|}{ Traits } \\
\hline & & $\begin{array}{c}\text { Plant height } \\
\text { (cm) }\end{array}$ & $\begin{array}{c}\text { Spike length } \\
(\mathrm{cm})\end{array}$ & $\begin{array}{l}\text { No. seeds } \\
\text { per spike }\end{array}$ & $\begin{array}{c}\text { Seeds weight } \\
\text { per spike }\end{array}$ & $\begin{array}{c}1000 \text { seeds } \\
\text { weight }(\mathrm{gm})\end{array}$ & $\begin{array}{c}\text { Leaf area } \\
\left(\mathrm{cm}^{2}\right)\end{array}$ & $\begin{array}{c}\text { Grain yield } \\
\text { (ton/ha) }\end{array}$ \\
\hline College of & $25 / 11$ & 83.767 a & $9.698 \mathrm{~b}$ & 37.267 a & $1.452 \mathrm{a}$ & $38.031 \mathrm{~b}$ & $31.727 \mathrm{~d}$ & $4.147 \mathrm{a}$ \\
\hline Agri. & $25 / 12$ & $78.100 \mathrm{~b}$ & $9.592 \mathrm{~b}$ & $37.483 \mathrm{a}$ & $1.398 \mathrm{~b}$ & 36.713 c & 38.377 a & $3.808 \mathrm{~b}$ \\
\hline & $25 / 11$ & $71.167 \mathrm{c}$ & $10.035 a$ & $34.483 \mathrm{~b}$ & $1.425 \mathrm{ab}$ & $39.732 \mathrm{a}$ & 34.482 c & $3.428 \mathrm{c}$ \\
\hline $\begin{array}{c}\text { Zenawa } \\
\text { Mean }\end{array}$ & $25 / 12$ & $\begin{array}{c}65.950 \mathrm{~d} \\
74.746\end{array}$ & $\begin{array}{c}8.032 \text { c } \\
9.339\end{array}$ & $\begin{array}{c}31.000 \text { c } \\
35.058\end{array}$ & $\begin{array}{c}1.283 \mathrm{c} \\
1.389\end{array}$ & $\begin{array}{c}39.788 \text { a } \\
38.566\end{array}$ & $\begin{array}{c}35.738 \mathrm{~b} \\
35.081\end{array}$ & $\begin{array}{c}3.153 \mathrm{~d} \\
3.634\end{array}$ \\
\hline
\end{tabular}

-The mean values followed by the same letter for each trait are not significantly different from each other

The results of combined analysis of variance for stability according to the method of Eberhart and Russell (9) for grain yield per hectare and its components are show in Table 8 , in which it is noticed that the mean square of environments (linear) were significant at $1 \%$ probability level for all traits indicating that the response to different environments is under genetic control ( 1 and 6), as well as the mean square of the linear component of genotypes $\mathrm{x}$ environments interaction when tested against pooled deviation appear to be significant at a $1 \%$ probability level for plant height, number of grains per spike, 1000 grains weight, and grain yield per hectare, but was not significant for the other traits Also, it 
is observed that the mean square of the pooled deviation of all the traits were significant at the probability level of $1 \%$, and this indicates that the main component of the differences in the validity of the genotypes for these traits is due to the deviation from the linear function and that its predictability is possible. The mean square of the linear component of the genotypes $x$ environments interaction for spike length, grain weight per spike, and leaf area were not significant, and this was due to the signification of pooled deviation, and this means that the deviation from the linear function contributes to the deviation in the validity of the genotypes for these three traits, and that the deviation considered one of the most important stability parameters (13). For the other traits, both components were significant, indicating that the differences in the validity of genotypes are due to both linear regression and deviation from the linear function. Table 8 also shows that the mean square was not significant for the following genotypes: Italy, for plant height and number of seeds per spike. Adana, Bora, Apst-6-85576 and Apst-36-85575 for grain yield, Criso for number and weight of grain per spike, Jehan 99 for plant height and number of grains per spike, Hawler for plant height, Buhoth-4 for number of grains per spike and leaf area, Apst -35-85574 for plant height, number of grains per spike and grain yield and Apst-12-85578 for grain weight per spike and grain yield, while the mean square of other cases reached the significant limit. Eberhart and Russell (9) suggested that the both components, linear (regression coefficient $\mathrm{B}_{\mathrm{i}}$ ) and nonlinear (deviation from regression $S^{2} d_{i}$ ) are important in predicting the stability of genotypes. When the regression coefficient is close to one and is associated with a value of deviation from the regression equal to zero, this indicates that the genotype has good response and stable for a wide range of environmental changes, and if the regression coefficient is greater than one, the genotype is described by the highest sensitivity to environmental changes, and it adapts in high-productivity (good) environments, but when the regression coefficient is less than one, this is an indication that the genotype characterized by high resistance to environmental changes (higher than moderate stability) and this increases the determination of adaptation to low-yielding environments (7).

Table 8. Results of the combined analysis of variance for stability for studied traits.

\begin{tabular}{|c|c|c|c|c|c|c|c|c|}
\hline \multirow[b]{2}{*}{ SOV } & \multirow[b]{2}{*}{ df } & \multicolumn{7}{|c|}{ Traits } \\
\hline & & $\begin{array}{c}\text { Plant height } \\
(\mathrm{cm})\end{array}$ & $\begin{array}{c}\text { Spike length } \\
(\mathrm{cm})\end{array}$ & $\begin{array}{l}\text { No. seeds } \\
\text { per spike }\end{array}$ & $\begin{array}{c}\text { Seeds weight } \\
\text { per spike }\end{array}$ & $\begin{array}{l}1000 \text { seeds } \\
\text { weight }(\mathrm{gm})\end{array}$ & $\begin{array}{c}\text { Leaf area } \\
\left(\mathrm{cm}^{2}\right)\end{array}$ & $\begin{array}{l}\text { Grain yield } \\
\text { (ton/ha) }\end{array}$ \\
\hline Gen. & 19 & 330.595 & 3.746 & 39.962 & 0.4575 & 146.187 & 120.322 & 1.476 \\
\hline$E+(G \times E)$ & 60 & 148.790 & 2.286 & 12.682 & 0.0164 & 11.995 & 59.584 & 0.349 \\
\hline E (Linear) & 1 & $3656.06 * *$ & $47.684 * *$ & $551.16 * *$ & $0.3298 * *$ & $131.46 * *$ & $458.05 * *$ & $11.35 * *$ \\
\hline GxE(Linear) & 19 & $191.063^{* *}$ & 1.893 & $6.794 * *$ & 0.0023 & $18.667 * *$ & 69.221 & $0.358 * *$ \\
\hline Pooled Dev. & 40 & $41.029 * *$ & $1.338 * *$ & $2.016 * *$ & $0.0152 * *$ & $5.838 * *$ & $45.045 * *$ & $\mathbf{0 . 0 7 0} * *$ \\
\hline Italy & 2 & 1.828 & $0.213 * *$ & 0.054 & $0.0026 *$ & $4.252 * *$ & $8.3911 * *$ & $\mathbf{0 . 0 7 7} * *$ \\
\hline Adana & 2 & $19.116 * *$ & $0.197 * *$ & $5.295 * *$ & $0.0577 * *$ & $17.159 * *$ & $42.982 * *$ & 0.015 \\
\hline Criso & 2 & $17.297 * *$ & $0.257 * *$ & 0.229 & 0.0013 & $5.809 * *$ & $122.92 * *$ & $0.207 * *$ \\
\hline Tamoz-2 & 2 & $45.746 * *$ & $4.612 * *$ & $1.487 * *$ & $0.0144 * *$ & $4.518 * *$ & $7.001 * *$ & $0.142 * *$ \\
\hline Bora & 2 & $10.373 * *$ & $2.675 * *$ & $1.4699 * *$ & $0.0037 * *$ & $1.189 * *$ & $70.122 * *$ & 0.003 \\
\hline Jehan 99 & 2 & 2.539 & $1.182 * *$ & 0.406 & $0.0032 *$ & $5.347 * *$ & $29.747 * *$ & $0.028 * *$ \\
\hline Hawler & 2 & 2.153 & $0.777 * *$ & $0.842 *$ & $0.0262 * *$ & $13.152 * *$ & 88.319** & $0.093 * *$ \\
\hline Adana 99 & 2 & $15.619 * *$ & $2.006 * *$ & $1.054 *$ & $0.0073 * *$ & $2.003 * *$ & $37.666 * *$ & $0.031 *$ \\
\hline TAWA-HI-3 & 2 & $68.848 * *$ & $0.463^{* * *}$ & $1.613 * *$ & $0.0053 * *$ & $2.674 * *$ & $12.504 * *$ & $0.021 *$ \\
\hline BA BA GA-3 & 2 & $122.645^{* * *}$ & $1.524 * *$ & $1.920 * *$ & $0.0458 * *$ & $11.578 * *$ & $\mathbf{8 5 . 7 3 5} * *$ & $0.112 * *$ \\
\hline Azadi & 2 & $48.483 * *$ & $2.844 * *$ & $2.159 * *$ & $0.0226 * *$ & $5.798 * *$ & $30.879 * *$ & $0.116 * *$ \\
\hline IPA 99 & 2 & $13.304 * *$ & $1.933 * *$ & $4.863 * *$ & $0.0089 * *$ & $2.002 * *$ & $12.552 * *$ & $0.029 * *$ \\
\hline IPA 95 & 2 & $12.763 * *$ & $0.652 * *$ & $6.777 * *$ & $0.0073 * *$ & $0.328 * *$ & $1.689 * *$ & $0.155 * *$ \\
\hline Buhoth-4 & 2 & $43.251 * *$ & $0.445 * *$ & 0.138 & $0.0678 * *$ & $10.722 * *$ & 0.214 & $0.045 * *$ \\
\hline Apst-35-85574 & 2 & 3.912 & $2.543 * *$ & 0.383 & $0.0119 * *$ & $13.339 * *$ & $111.11 * *$ & 0.013 \\
\hline Apst-33-85577 & 2 & $17.898 * *$ & $0.159 * *$ & $1.152 *$ & $0.0029 *$ & $3.859 * *$ & $150.49 * *$ & $0.264 * *$ \\
\hline Apst-6-85576 & 2 & $164.463 * *$ & $0.679 * *$ & $2.609 * *$ & $0.0034 * *$ & $1.517 * *$ & $3.357 * *$ & 0.004 \\
\hline Apst-36-85575 & 2 & $56.987 * *$ & $0.425 * *$ & $2.756 * *$ & $0.0084 * *$ & $1.525 * *$ & $24.906 * *$ & 0.015 \\
\hline Apst-12-85578 & 2 & $50.618 * *$ & $3.179 * *$ & $3.206 * *$ & 0.00001 & $1.759 * *$ & $29.849 * *$ & 0.005 \\
\hline Apst-26-85579 & 2 & $102.735 * *$ & $1.848 * *$ & $1.912 * *$ & $0.0041 * *$ & $8.225 * *$ & $30.464 * *$ & $0.029 *$ \\
\hline Pooled error & 16 & & & & & & & \\
\hline & 0 & 1.486 & 0.0343 & 0.268 & 0.0007 & 0.058 & 0.251 & 0.007 \\
\hline
\end{tabular}

$(* *)$ and $(*)$ Significant at $1 \%$ and $5 \%$ probability respectively 
The linear regression of the average of any of the seven traits of the single genotype over the average of all genotypes in each environment resulted in regression coefficients values ranging between (-0.7729 and 3.1715) for plant height, (-0.9304 and 2.5496) for spike length, (0.1834 and 1.7657) for number of grains per spike, $(0.3748$ and 1.6751$)$ for grain weight per spike, (-2.4533 and 3.3226) for 1000 grains weight, $(-2.1617$ and 3.8184$)$ for leaf area, and between (-1.0355 and 2.4337) for grain yield per hectare. These large variations in the regression coefficients, especially for plant height, spike length, 1000 grain weight, leaf area and grain yield per hectare indicate the different response genotypes to environmental changes (Table 9). From the obtained results, it is revealed that plant height trait that genotypes $1,2,4,6,7,8$, $11,15,16$ and 19 had non-significant regression coefficients from unity $\left(B_{i}=1\right)$, among which the genotypes $2,6,8$ and 11 were distinguished by a good mean performance for plant height, and the deviation from the regression for the genotypes $1,6,7$ and 15 are not significant, and this indicates that they are characterized by high stability. As for the remainder genotypes (those with an insignificant regression coefficient from unity), their stability in different environments was moderate because the values of the deviation from the regression are significant. For the trait of the spike length, the regression coefficient was not significant in most genotypes excluding 5, 8, 12, 15 and 20, and given that the deviation from the regression was significant, their stability in different environments was moderate, suggesting that the genotypes 6,13 and 15 had a good mean performance for the spike length, and more than the general mean of the trait. Genotypes $3,4,10,11,13,16$, and 18 were distinguished by a regression coefficient that was not significant from unity for the number of grains per spike, and the deviation from the regression was also insignificant for genotype 3 (Criso), thus, it is considered highly stable for this trait, and since the regression coefficient is greater than one, for genotype 1 (Italy), it was found that it responded to good environments, while both genotypes 6,14 and 15 had a regression coefficient less than one, and therefore they grow well in inappropriate environments. All genotypes were characterized by an insignificant regression coefficient for grains weight per spike, and in contrast, the deviation from the regression was insignificant in both 3 (Criso) and 19 (Apst12-85578) genotypes, and accordingly they were surpassed by high stability for different environmental conditions. While the other genotypes considered moderate in their stability for this trait. Regarding 1000 grains weight trait, none of the genotypes showed high stability for environmental changes, due to the significant deviation from the regression for all of them, while the genotypes $3,12,15$, 16 and 20 showed moderate stability because their regression coefficient was not significant from unity, while the stability of the remainder genotypes was difficult to predict because both components of stability were significant. Genotype 14 (Buhoth-4) showed high stability for the different environmental conditions for leaf area trait, due to the insignificance of both the regression coefficient and the deviation from the regression and at the same time its mean performance for the trait was good and higher in their value than the general mean, while the genotypes 9, 16 and 18 were moderate in their stability, because the regression coefficient was not significant, and the deviation from the regression was significant. Finally, for the grain yield trait, both components of stability (regression coefficient and deviation from regression) were not significant in genotypes 2, 5, 17 and 19 , and thus they are considered to be highly stable in different environments, and at the same time the mean of grain yield in genotypes 5 and 19 was high and higher than the general mean, while genotypes $3,4,6,7$, 16 and 20 showed moderate stability because the deviation from their regression was significant versus the insignificance of the regression coefficient and because the regression coefficient of genotype 17 (Apst36-85575) is greater than unity, and the deviation from the regression is not significant, then it responds to good environments only, while genotype 14 (Apst35-85574) appeared to grow well in inappropriate environments, because the regression coefficient smaller than unity and 
the deviation from the regression is not significant.

Table 9. Stability parameters for the studied traits.

\begin{tabular}{|c|c|c|c|c|c|c|c|c|}
\hline \multirow{2}{*}{ Genotypes } & \multicolumn{2}{|c|}{ Plant height (cm) 2} & \multicolumn{2}{|c|}{ Spike length $(\mathrm{cm})$} & \multicolumn{2}{|c|}{ No. seeds per spike } & \multicolumn{2}{|c|}{ Seeds weight per spike } \\
\hline & $\mathbf{B}_{\mathbf{i}}$ & $\mathbf{S}^{2} \mathbf{d}_{\mathrm{i}}$ & $\mathbf{B}_{\mathbf{i}}$ & $\mathbf{S}^{2} \mathbf{d}_{\mathrm{i}}$ & $\mathbf{B}_{\mathrm{i}}$ & $\mathbf{S}^{2} \mathbf{d}_{\mathrm{i}}$ & $\mathbf{B}_{\mathrm{i}}$ & $S^{2} d_{i}$ \\
\hline Italy & 0.7781 & -28.999 & 1.0217 & $-0.31 * *$ & 1.3133 & -1.173 & 0.6538 & $-0.001 *$ \\
\hline Adana & 0.9449 & $-11.71 * *$ & 1.2116 & $-0.33 * *$ & 1.5601 & $4.07 * *$ & 0.6330 & $0.054 * *$ \\
\hline Criso & -0.1291 & $-13.54 * *$ & 0.8151 & $-0.27 * *$ & 1.2392 & -0.997 & 0.5642 & -0.003 \\
\hline Tamoz-2 & 0.9927 & $14.92 * *$ & 1.0513 & $4.09 * *$ & 1.1879 & $0.261 * *$ & 1.2606 & $0.011 * *$ \\
\hline Bora & 0.0987 & $-20.45 * *$ & -0.6752 & $2.15 * *$ & 0.3495 & $0.243 * *$ & 0.7439 & $0.00001 * *$ \\
\hline Jehan 99 & 0.9357 & -28.288 & 0.4695 & $0.66 * *$ & 0.2652 & -0.821 & 0.7499 & $-0.001 *$ \\
\hline Hawler & 1.3527 & -28.674 & 1.2447 & $0.25 * *$ & 0.6944 & $-0.384 *$ & 1.5116 & $0.022 * *$ \\
\hline Adana 99 & 1.3865 & $-15.21 * *$ & 2.5496 & $1.48 * *$ & 1.3556 & $-0.173 *$ & 1.5205 & $0.003 * *$ \\
\hline TAWA-HI-3 & 2.1593 & $38.02 * *$ & 1.0145 & $-0.06 * *$ & 1.4041 & $0.386 * *$ & 1.3848 & $0.002 * *$ \\
\hline BA BA GA-3 & 3.1715 & $91.82 * *$ & 1.4555 & $1.001 * *$ & 0.8854 & $0.694 * *$ & 0.9715 & $0.042 * *$ \\
\hline Azadi & 1.0591 & $17.65 * *$ & 1.5414 & $2.320 * *$ & 1.2033 & $0.933 * *$ & 0.9217 & $0.019 * *$ \\
\hline IPA 99 & 2.1343 & $-17.52 * *$ & 1.9172 & $1.409 * *$ & 1.7657 & $3.636 * *$ & 1.3703 & $0.005 * *$ \\
\hline IPA 95 & 2.2217 & $-18.06 * *$ & 0.9683 & $0.129 * *$ & 0.9688 & $5.551 * *$ & 0.8151 & $0.003 * *$ \\
\hline Buhoth-4 & 2.3555 & $12.43 * *$ & 0.9816 & $-0.08 * *$ & 0.3128 & -1.0882 & 1.0316 & $0.064 * *$ \\
\hline Apst-35-85574 & 0.6732 & -26.914 & -0.9304 & $2.019 * *$ & 0.3052 & -0.843 & 1.3879 & $0.008 * *$ \\
\hline Apst-33-85577 & -0.7729 & $-12.93 * *$ & 0.8903 & $-0.36 * *$ & 0.8567 & $-0.075 *$ & 0.7049 & $-0.0009 *$ \\
\hline Apst-6-85576 & -0.4011 & $133.64 * *$ & 1.6627 & $0.156 * *$ & 1.5705 & $1.383 * *$ & 0.3748 & $-0.0004 * *$ \\
\hline Apst-36-85575 & $\mathbf{0 . 0 5 0 7}$ & $26.16 * *$ & 1.6221 & $-0.09 * *$ & 1.1223 & $1.529 * *$ & 1.6751 & $0.005 * *$ \\
\hline Apst-12-85578 & 0.7550 & $19.79 * *$ & 1.5072 & $2.656 * *$ & 1.4567 & $1.979 * *$ & 0.9205 & -0.004 \\
\hline Apst-26-85579 & 0.2336 & $71.91 * *$ & -0.3187 & $1.325 * *$ & 0.1834 & $0.685 * *$ & 0.8043 & $0.0003 * *$ \\
\hline $\mathrm{SE}\left(\mathbf{B}_{\mathrm{i}}\right)$ & 0.474 & & 0.749 & & 0.271 & & 0.961 & \\
\hline \multirow[t]{2}{*}{ Genotypes } & \multicolumn{2}{|c|}{$\begin{array}{c}1000 \text { seeds weight } \\
(\mathrm{gm})\end{array}$} & \multicolumn{2}{|c|}{ Leaf area $\left(\mathrm{cm}^{2}\right)$} & \multicolumn{2}{|c|}{ Grain yield (ton/ha) } & & \\
\hline & $\mathbf{B}_{\mathbf{i}}$ & $\mathbf{S}^{2} \mathbf{d}_{\mathrm{i}}$ & $\mathbf{B}_{\mathbf{i}}$ & $\mathbf{S}^{2} \mathbf{d}_{\mathrm{i}}$ & $\mathbf{B}_{\mathbf{i}}$ & $\mathbf{S}^{2} \mathbf{d}_{\mathrm{i}}$ & & \\
\hline Italy & 2.9053 & $0.812 * *$ & -2.1239 & $-9.84 * *$ & 1.4054 & $0.021 * *$ & & \\
\hline Adana & -1.6561 & $13.72 * *$ & 0.0036 & $24.75 * *$ & 0.9625 & -0.042 & & \\
\hline Criso & 1.5150 & $2.369 * *$ & 1.5880 & $104.9 * *$ & 1.2858 & $0.150 * *$ & & \\
\hline Tamoz-2 & -0.1616 & $1.078 * *$ & 0.0030 & $-11.23 * *$ & 0.8548 & $0.085 * *$ & & \\
\hline Bora & 0.0718 & $-2.251 * *$ & -0.2940 & $51.89 * *$ & 0.7609 & -0.053 & & \\
\hline Jehan 99 & -0.1124 & $1.907 * *$ & 2.2549 & $11.52 * *$ & 0.947 & $-0.03 * *$ & & \\
\hline Hawler & -2.4533 & $9.713 * *$ & 3.8184 & $70.09 * *$ & 1.2059 & $\mathbf{0 . 0 3 7} * *$ & & \\
\hline Adana 99 & 2.1479 & $-1.44 * *$ & 3.0824 & $19.44 * *$ & 2.4337 & $-0.025 *$ & & \\
\hline TAWA-HI-3 & 0.1553 & $-0.77 * *$ & 0.8972 & $-5.72 * *$ & 2.2102 & $-0.035 *$ & & \\
\hline BABAGA-3 & 2.9669 & $8.138 * *$ & -0.7560 & $67.51 * *$ & 1.7907 & $0.056 * *$ & & \\
\hline Azadi & 2.7409 & $2.358 * *$ & -0.1349 & $12.65 * *$ & -1.0355 & $0.059 * *$ & & \\
\hline IPA 99 & 1.0326 & $-1.44 * *$ & -0.8774 & $-5.68 * *$ & -0.3641 & $-0.03 * *$ & & \\
\hline IPA 95 & 0.0636 & $-3.11 * *$ & 3.1707 & $-16.5 * *$ & 0.3826 & $0.099 * *$ & & \\
\hline Buhoth-4 & 3.2344 & $7.282 * *$ & 1.4570 & -18.014 & 0.5580 & $-0.01 * *$ & & \\
\hline Apst-35-85574 & 1.0688 & $9.899 * *$ & 2.8399 & $92.88 * *$ & 0.5077 & -0.043 & & \\
\hline Apst-33-85577 & 0.6072 & $0.419 * *$ & 1.7579 & $132.3 * *$ & 1.3219 & $0.208 * *$ & & \\
\hline Apst-6-85576 & 3.3226 & $-1.92 * *$ & -2.1617 & $-14.9 * *$ & 1.2107 & -0.052 & & \\
\hline Apst-36-85575 & -1.1535 & $-1.92 * *$ & 1.0916 & $6.675 * *$ & 1.6807 & -0.041 & & \\
\hline Apst-12-85578 & 2.6259 & $-1.68 * *$ & 2.4864 & $11.62 * *$ & 1.0286 & -0.052 & & \\
\hline Apst-26-85579 & 1.0788 & $4.785 * *$ & 1.8968 & $12.24 * *$ & 0.8534 & $-0.027 *$ & & \\
\hline $\mathrm{SE}\left(\mathrm{B}_{\mathrm{i}}\right)$ & 0.942 & & 1.402 & & 0.352 & & & \\
\hline
\end{tabular}

(**) and (*) Significant at $1 \%$ and $5 \%$ probability respectively

According to the method of the stability triangle for this trait (Figure 1), it is noticed that genotypes 2 and 19 were close to the regression line and the general mean line of the trait to their left and its right, respectively, confirming their high stability to different environmental conditions, as well as the two genotypes 1 and 7 which are located a little further from the regression line to the left of the general mean line and the genotype 5 which falls to the right of the regression line (indicating the high performance of the grain yield) and slightly outside the stability triangle, and according to this method also the genotypes 2, 6 and 7 counted with high stability for grain yield being very close to the lines of the regression coefficient and the general mean within the stability triangle. 


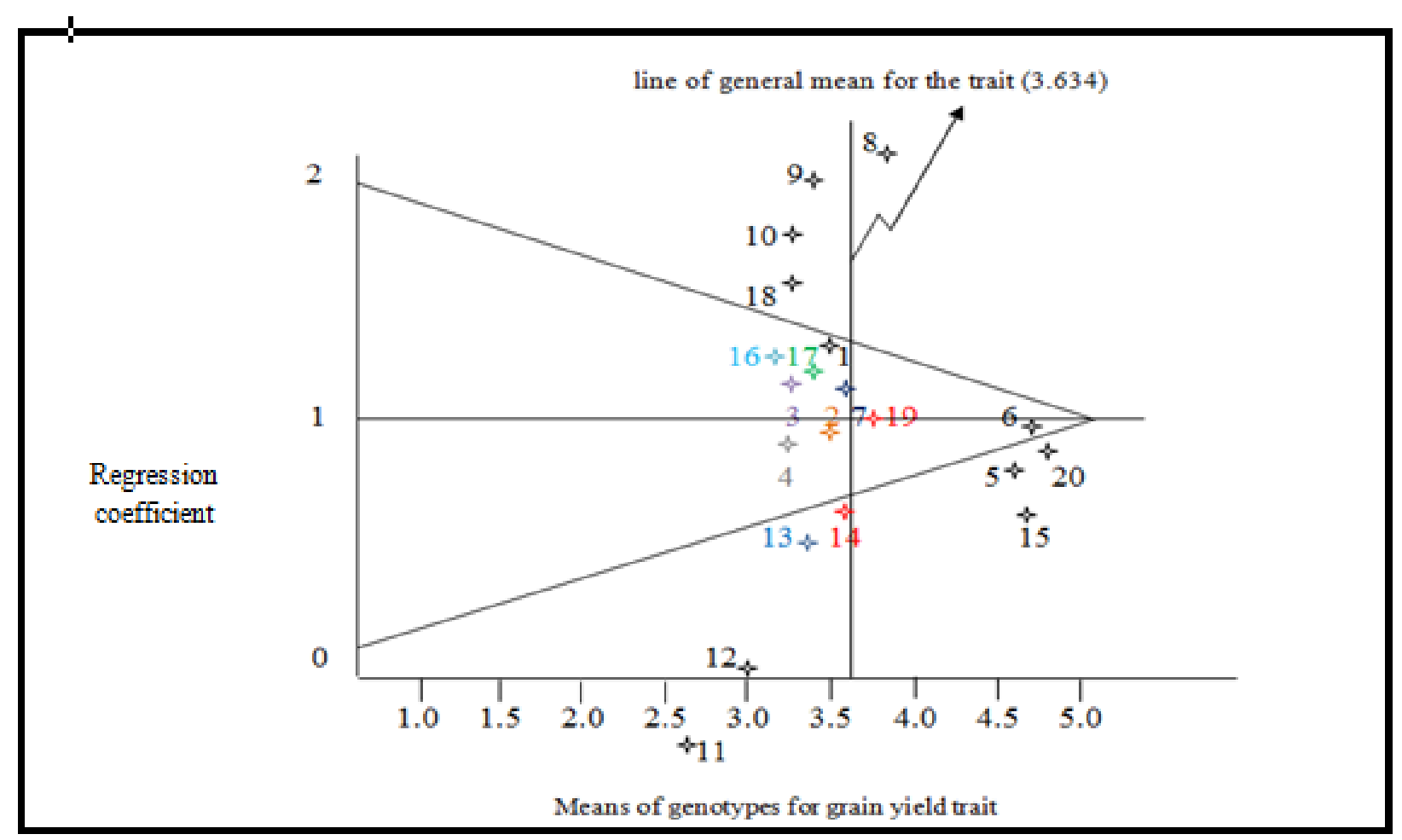

Figure (1): Distribution of genotypes in the stability triangle for grain yield/ha

It is concluded from the foregoing that the genotype Apst-12-85578 was highly stable for grains weight per spike and final grain yield, and moderate for plant height and spike length, followed by the Criso genotype with high stability for number and weight of grains per spike and high response for spike length, 1000 grain weight and grain yield only in good environments, then the three genotypes, Adana, Bora and Apst-6-85576 which showed high stability for grain yield. The genotype Apst-33-85577 was characterized by moderate stability for all traits, and these results allow the possibility of making use of high and moderate stability in future cross-breeding programs to find new varieties that are characterized by good productivity and quality specifications and stable in a wide range of environmental changes, in addition to the possibility of expanding their cultivation over a wide range of environmental conditions.

\section{REFERENCES}

1. Al- Falluji S.J. 2018. Value chain of wheat crop in Baghdad province/Iraq an applied study for year 2017. Iraqi Journal of Agricultural Sciences -1028:49(5):763-774

2. Al-Zubaidy, K. M. D. and M. A. H. AlFalahy. 2016. Principle and Procedures of Statistics and Experimental Design. Duhok University Press, Iraq
3. Al-Zubaidy, Kh. M. D. and Kh. K. A. AlJubouri. 2016. Design and Analysis of Genetic Experiments. Al-Wadah Publishing House, Kingdom of Jordan - Amman, Tigris Library for Printing, Publishing and Distribution, Republic of Iraq - Baghdad.

4. Arain, M. A., M. A. Sial, M. A. Rajput and A. A. Mirbahar. 2011. Yield stability in bread wheat genotypes. Pak. J. Bot., 43(4): 20712074

5. Budak, N. 2000. Heritability, correlation and genotype $\mathrm{x}$ year interaction of grain yield, test weight and protein content in durum wheat. Society of Field Crop Sci., 5(2): 13011311

6. Dawod, Kh. M. 2008. Genetic stability in some cotton varieties, Gossypium hirsutum L. Proceedings of the Fourth Agricultural Conference, College of Agriculture, Tikrit University, April 29-30, 2008

7. Dawod, Kh. M., A. A. Muhammad and Kh. H. Kanoush. 2011. Environmental genetic overlap and phenotypic stability of yellow corn (Zea mays L.). Al-Kufa Journal of Agricultural Sciences, 3(2): 68-76

8. Demir, I., I. Turgut. 1999. General Plant Improvement. Ege Univ. Zira. Fak. Arrow. No: 496:138. Izmer

9. Eberhart, S. A. and W. A. Russell. 1966. Stability parameters for comparing varieties. Crop Sci. 6:36-40 
10. Ellis, R. H. R., R. J. Sumer field and E. H. Roberts. 1997. Adaptation of soybean. World Soybean Research Conference. Bangkok, Thailand pp. 334.

11. Finlay, W. and G. N. Wilkinson. 1963. The analysis of adaptation in a plant breeding programme. Aust. J. Agric. Res., 14: 742-754

12. Frison, E. A., J. Cherfas and T. Hodgkin 2011. Agricultural biodiversity is essential for a sustainable improvement in food and nutrition security. Sustainability 3: 238-253

13. Gill, S. S. and T. H. Singh 1982. Stability parameters for yield and yield components in upland cotton (Gossypium hirsutum L.). Egypt. J. Genet. Cytol., 11: 9-13

14. Goldringer, I., E. Serpolay F. Rey and A. Costanzo2017. Varieties and populations for on-farm participatory plant breeding. Diversifood Innovation Factsheet 2. Available online:

http://www.diversifood.eu/wpcontent/uploads/ 2018/06/Diversifood_innovation_factsheet2_V arietiesPopulations.pdf

15. Hamam, K.A., Abdel-Sabour and G. A. Khaled . 2009. Stability of wheat genotypes under different environments and their evaluation under sowing dates and nitrogen Fertilizer levels. Australian Journal of Basic and Applied Sciences, 3(1): 206-217

16. Kahiluoto, H., J. Kaseva, J. Balek, J. E. Olesen, M. Ruiz-Ramos, A. Gobin, K. C. Kersebaum, J. Takác, F. Ruget and R. Ferrise. 2019. Decline in climate resilience of European wheat. Proc. Natl. Acad. Sci., 116, 123-128.

17. Khan, A. J., F. Azam, A. Ali, M. Tariq, M. Amin and T. Muhammad.2007. Wide and specific adaptation of bread wheat inbred lines for yield under rainfed conditions. Pakistan J. Bot.,39:67-71
18. Liu, B., P. Martre, F. Ewert, J. R. Porter, A. J. Challinor, C. Müller, A. C. Ruane, K. Waha, P. J. Thorburn and P. K. Aggarwal. 2018. Global wheat production with 1.5 and 2.0 _C above pre-industrial warming. Glob. Chang. Biol. 25, 1428-1444

19. Mahmood Z. H., A. S. Bashar S. A. Nasir. 2018. Estimating profit and cost functions and economic and technical efficiencies of wheat production Nejaf province - Al-Abbassi Township (a case study) for season 2016. Iraqi Journal of Agricultural Sciences 1028:49(3):000-004

20. Manu, B. T. and U. J. S. P. Rao. 2008. Influence of size distribution of proteins, thiol and disulfide content in whole wheat flour on rheological and Chapati texture of Indian wheat varieties. Elsevier Food Chemistry (110): 888-895

21. Reiss, E.R. and L. E. Drinkwater. 2018. Cultivar mixtures: A meta-analysis of the effect of intraspecific diversity on crop yield. Ecol. Appl. 2018, 28, 62-78

22. Rijib M. Z. and O.K.Jbara. 2016. Effect of variation in the measurement of space categories of wheat farms in Sulaymaniyah wheat on the level of economic efficiency and estimate the size of the efficiency achieved optimal resources. The Iraqi Journal of Agricultural Sciences - 84(1):6841-6844

23. Sial, M. A., M. A. Arain, M. H. Naqvi, A.M. Soomro,S. Laghari, N. A Nizamani and A. Ali. 2003.Seasonal effects and genotypic responses for grain yield in semi dwarf wheat. Asian J. Plant Sciences, 02(15-16): 1097-1101 24. Yan, W. and I. Rajcan (2002). Biplot analysis of test sites and trait relations of soybean in Ontario. Crop Sci., 42: 11-20

25. Yang, R. C. and R. J. Baker. 1991. Genotype-environment interactions in two wheat crosses. Crop Sci., 31: 83-87. 